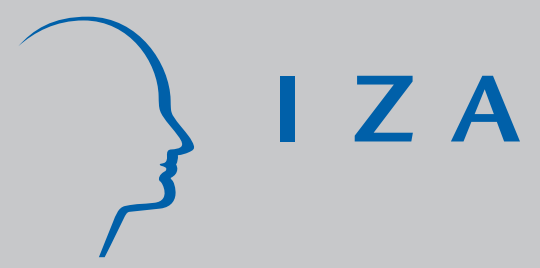

IZA DP No. 1185

Exporting Firms Do Not Pay Higher Wages, Ceteris Paribus. First Evidence from Linked Employer-Employee Data

Thorsten Schank

Claus Schnabel

J oachim Wagner

J une 2004 


\title{
Exporting Firms Do Not Pay Higher Wages, Ceteris Paribus. First Evidence from Linked Employer-Employee Data
}

\author{
Thorsten Schank \\ University of Erlangen-Nuremberg \\ Claus Schnabel \\ University of Erlangen-Nuremberg \\ Joachim Wagner \\ University of Lueneburg and IZA Bonn
}

Discussion Paper No. 1185

June 2004

IZA
P.O. Box 7240
53072 Bonn
Germany

Phone: +49-228-3894-0

Fax: +49-228-3894-180

Email: iza@iza.org

\begin{abstract}
Any opinions expressed here are those of the author(s) and not those of the institute. Research disseminated by IZA may include views on policy, but the institute itself takes no institutional policy positions.

The Institute for the Study of Labor (IZA) in Bonn is a local and virtual international research center and a place of communication between science, politics and business. IZA is an independent nonprofit company supported by Deutsche Post World Net. The center is associated with the University of Bonn and offers a stimulating research environment through its research networks, research support, and visitors and doctoral programs. IZA engages in (i) original and internationally competitive research in all fields of labor economics, (ii) development of policy concepts, and (iii) dissemination of research results and concepts to the interested public.
\end{abstract}

IZA Discussion Papers often represent preliminary work and are circulated to encourage discussion. Citation of such a paper should account for its provisional character. A revised version may be available on the IZA website (www.iza.org) or directly from the author. 
IZA Discussion Paper No. 1185

June 2004

\section{ABSTRACT}

\section{Exporting Firms Do Not Pay Higher Wages, Ceteris Paribus. First Evidence from Linked Employer-Employee Data}

18 studies using data from 20 highly developed, developing, and less developed countries document that average wages in exporting firms are higher than in non-exporting firms from the same industry and region. The existence of these so-called exporter wage premia is one of the stylized facts found in the emerging literature on the microeconometrics of international trade. This paper uses a large and rich set of linked employer-employee data from Germany to demonstrate that these premia vanish when individual characteristics of the employees and of the work place are controlled for.

JEL Classification: F10, D21, L60

Keywords: exports, wages, exporter wage premia, linked employer-employee data, Germany

Corresponding author:

Joachim Wagner

Institute of Economics

Campus 4.210

University of Lueneburg

21332 Lueneburg

Germany

Email: wagner@uni-lueneburg.de 


\section{MOTIVATION}

Some ten years ago Bernard and Jensen (1995) published a Brookings paper on "Exporters, Jobs, and Wages in U.S. Manufacturing" that used hundreds of thousands of plant level data to provide facts and figures on exporting plants compared to their non-exporting counter-parts. One of the new and exciting findings documented in this paper is that exporters tend to pay higher wages and benefits: Average wages and benefits (per worker, per production worker, and per non-production worker) are higher in exporting plants than in non-exporting plants of all size classes. Exporter wage premia are statistically significant for all categories of wages and benefits after controlling for capital per worker, size of plant, multi-plant dummy, industry, year, plant age, and region. Coefficients of exporter status dummies are statistically significant in fixed effects regressions controlling for capital per worker, hours per worker, size of plant, and year.

The Bernard and Jensen (1995) paper started a literature. Table 1 provides a synopsis ${ }^{1}$ of 18 studies covering 20 different countries from highly developed economies like the U.S., Germany, and Sweden, and emerging economies like Taiwan, Korea, and Mexico, to a transition country (Estonia) and least developed Sub-Saharan African economies like Burundi or Ethiopia. The empirical strategies used in these papers replicate (sometimes only partly) the approach introduced by Bernard and Jensen, and the results regarding the exporter wage premia are broadly consistent with the findings from the pioneering study.

\section{[Table 1 near here]}

An open question not dealt with in this literature is whether these exporter wage premia do indeed indicate that exporting plants pay higher wages in the sense that comparable workers are better paid when working on a comparable work place for an exporter, i.e. ceteris paribus. ${ }^{2}$ Given that all the empirical studies listed in Table 1 use average data at the plant or firm level, individual characteristics of the

\footnotetext{
We intend to keep this synopsis comprehensive and up-to-date. Readers who are aware of other studies not covered or of more recent (published) versions of studies listed are kindly asked to send an e-mail to <wagner@uni-lueneburg.de>.

2 Another question that is taken into account in this literature is the direction of causality: Do exporters pay higher wages because they are exporters? Did they pay higher wages before they started to export? Do wages increase faster in firms that (started to) export than in comparable non-exporting firms? In this paper we focus on the question whether the premia do exist at all or not. For a discussion of the pitfalls of the standard approach used to investigate the direction of causality, and a solution based on a matching approach, see Wagner (2002).
} 
workers that might influence their productivity (and, therefore, their wages) cannot be taken into account, and certain characteristics of the work place that might call for compensating wage differentials are not represented adequately. This shortcoming has been recognized from the outset: Commenting on the presentation of the paper by Bernard and Jensen, Robert Z. Lawrence argued that "the impact of exports, while positive and statistically significant, is considerably reduced once the effects of capital intensity, industry, plant scale, and location are controlled for. One suspects, moreover, that the premiums would be even further reduced if the authors were able to control for worker characteristics. Thus the wage benefits that are attributable solely to exporting appear to be rather small." (Bernard and Jensen 1995, p. 113f.)

Besides providing a synopsis of the literature on exporter wage premia in Table 1 this paper contributes to the literature by testing for the existence of these premia when individual characteristics of the employees and the work place are controlled for in an appropriate way. To do so we use a rich German linked employeremployee data set, a type of data that has not been used to investigate this topic before. The rest of the paper is organized as follows: Section 2 introduces the data set while section 3 explains our line of econometric investigation. Section 4 provides results for exporter wage premia based on plant level data and on linked employer-employee data using information for both individual workers and the plants they are working in. Section 5 concludes.

\section{THE LINKED EMPLOYER-EMPLOYEE DATA SET}

The use of matched employer-employee data has recently become popular as it allows a more detailed analysis of economic relationships. In particular, various analyses of the labor market can benefit from the availability of employeremployee data. ${ }^{3}$ In this paper, we use the LIAB, which combines the employment statistics of the German Federal Labor Services with plant level data from the IAB Establishment Panel.

The employment statistics (cf. Bender, Haas and Klose 2000) cover all employees and trainees subject to social security. They exclude, among others, the selfemployed, family workers, a subgroup of civil servants ("Beamte"), students enrolled in higher education and those in marginal employment. The employment

\footnotetext{
A survey of analyses using matched employer-employee data sets can be found in Abowd and
} Kramarz (1999). 
statistics cover nearly $80 \%$ of all employed persons in western Germany and about $85 \%$ in eastern Germany. They are collected by the social insurance institutions for their purposes according to a procedure introduced in 1973 and are made available to the Federal Employment Services. Notifications are prescribed at the beginning and at the end of a person's employment in a plant. In addition an annual report for each employee is compulsory at the end of a year. Misreporting is legally sanctioned. The employment statistics contain information on an employee's occupation, the occupational status, and gross earnings up to the contribution assessment ceiling, and on individual characteristics like sex, age, nationality, marital status, and qualification. Each personnel record also contains the establishment identifier, the industry, and the size of the plant.

Starting in 1993, the IAB Establishment Panel (cf. Kölling 2000) is drawn from a stratified sample of the plants included in the employment statistics, where the strata are defined over industries and plant sizes (large plants are oversampled), but the sampling within each cell is random. In 1993, the sample started with 4,265 plants, covering $0.27 \%$ of all plants in western Germany ( 2 million) and $11 \%$ of total employment (29 million). In 1996, the eastern German establishment panel started with 4,313 establishments representing $1.10 \%$ of all plants (391 thousand) and $11 \%$ of total employment ( 6 million). Altogether, the number of establishments interviewed increased until the year 2003 up to nearly 16,000, in order to allow regional analysis at the federal state level. The IAB Establishment Panel has been set up for the needs of the Federal Labor Services to provide further information about the demand side of the labor market. Therefore, detailed information on the composition of the workforce and its development through time constitutes a major part of the questionnaire. Further questions include information on training and further education, wages, working time, business activities, establishment policies, and general information about the plant. Other topics, for instance, questions on innovations or the flexibility of labor, are asked biannually or triannually.

The LIAB is created by linking the employment statistics and the IAB Establishment Panel through a plant identifier which is available in both data sets. ${ }^{4}$ This matched employer-employee data set, which is unique for Germany, currently comprises the years 1993 to 1997. Since precise information on the collective bargaining regime of plants is not available before 1995, we can only make use of

The LIAB data are confidential but not exclusive. Starting in 2005, they will be available for noncommercial research by visiting the data access center of the German Federal Labor Services at the IAB in Nuremberg, Germany. Researchers interested in replications or extensions of our work may contact the first author (e-mail: Thorsten.Schank@wiso.uni-erlangen.de) for a copy of the Stata do-files used to produce the results reported here. 
the waves 1995 to 1997 . We exclude establishments that are located in the eastern part of Germany since the economic situation (and the level of wages) in post-communist eastern Germany still differs considerably from that in western Germany. Also, we focus on the manufacturing sector since exports are only of minor importance in the service sector. Therefore, in the regressions we end up with a sample of $1,860,710$ observations of 903,614 employees in 2,948 establishments.

\section{ECONOMETRIC APPROACH}

The basic specification for our econometric investigations relates the wage $\left(w_{i t}\right)$ of individual $i$ at time $t$ to characteristics of the individual $\left(X_{i t}\right)$ and the establishment $\left(Z_{j(i t))}\right.$.

$\ln w_{i t}=X_{i t} \beta+\bar{Z}_{1, j(i t)} \gamma_{1}+Z_{2, j(i t)} \gamma_{2}+J_{t(i j)} \delta+\varepsilon_{i t}$

$X_{i t}$ is a vector of individual characteristics which are typically included in the empirical literature on wages. These comprises the following variables, all of which are available from the employment statistics: the age of the employee, the squared age of the employee, a gender dummy, dummies for the occupational status of the employee (unskilled blue-collar, skilled blue-collar, master craftsman/foreman, white-collar worker), dummies indicating that the employee is working part-time, is married, is of non-German nationality, as well as 98 occupational dummies.

$Z_{j(i t)}$ defines characteristics of the plant, where the subscript $j(i t)$ indicates that at time $t$ all workers in a plant $j$ share the same value of $Z$. This vector of plant level variables can be split up into two subsets $Z_{1}$ and $Z_{2}$. The former includes those characteristics which can be obtained either directly from the IAB Establishment Panel or by aggregating individual level information from the employment statistics, whereas the latter comprises variables only available from the IAB panel. In particular, $Z_{1}$ includes the logarithm and the squared logarithm of the number of employees in the establishment and the proportions of female workers, of foreign workers, of workers with a graduate degree and of part-time employees. More precisely, we use the notation $\bar{Z}_{1}$ to take account of the fact that this subset captures plant averages of employee characteristics as compared to $Z_{2}$, which reflects characteristics of the plant. These include information on exports (explained below), two dummies for the economic performance of the establishment, dummies indicating that overtime work exists, that shift work exists, 
that the plant applies a collective bargaining agreement (separately for sectoral and plant level agreements), an index for the state of technology in the plant, a dummy indicating that the plant has been founded within the last five years as well as nine federal state dummies and 13 industry dummies. Equation (1) also includes a vector of year dummies $J_{t(j, i)}$, where the subscript $t(i, j)$ indicates that the time effect in $t$ is constant for all workers $i$ and all plants $j$. $\varepsilon_{i t}$ denotes the error component.

Aggregating Equation (1) at the plant level (i.e. aggregating over all employees $i$ at time $t$ in a plant $j$ ) yields the following relationship:

$\ln \bar{w}_{j t}=\bar{X}_{j t} \beta+\bar{Z}_{1, j t} \gamma_{1}+Z_{2, j t} \gamma_{2}+J_{t(j)} \delta+\bar{\varepsilon}_{j t}$

where $\bar{w}_{j t}=\sum_{(i t) \in j t} w_{i t} / N_{j t}, \bar{X}_{j t}=\sum_{(i t) \in j t} X_{i t} / N_{j t}$ and $\bar{\varepsilon}_{j t}$ analogously $\left(N_{j t}\right.$ denotes the number of employees in plant $j$ at time $t$ ).

Our preferred specification to estimate the exporter wage premia is clearly given by Equation (1), since it controls for individual as well as plant level heterogeneity. However, we also want to investigate whether the obtained estimate changes when the specification is more restrictive. Therefore, we start off by assuming we had only a plant level data set at hand, i.e. we mimic the framework of those studies listed in Table 1 and estimate the following relationship which we denote as Model 1:

$$
\ln \bar{w}_{j t}=\bar{Z}_{1, j t} \gamma_{1}+Z_{2, j t} \gamma_{2}+J_{t(j)} \delta+\bar{\varepsilon}_{j t}
$$

We should point out again, that at this first stage all variables are based on information from the IAB panel (although information on $\bar{w}_{j t}$ and $\bar{Z}_{1, j t}$ would be available from the employment statistics as well). In the second step, we also include individual level information which has been aggregated to the plant level $\left(\bar{X}_{j t}\right)$. This is equivalent to estimating Equation (2). Henceforth, we refer to this specification as Model 2, which combines information from the employment statistics (the $\left.\bar{X}_{j t}\right)$ with information from the IAB panel $\left(\bar{w}_{j t}, \bar{Z}_{1, j t}\right.$ and $\left.Z_{2, j t}\right)$. As stated above, $\bar{Z}_{1, j t}$ can also be extracted from the individual level data, and our Model 3 is based on this information from the employment statistics. Next, we replace our aggregate wage variable from the IAB panel with the plant level average of the individual wages reported in the employment statistic (Model 4). Hence, when estimating Model 4 , only $Z_{2, j t}$ stems from the IAB panel, whereas $\bar{w}_{j t}$ as well as $\bar{X}_{j t}$ and $\bar{Z}_{2, j t}$ are extracted from the employment statistics. Finally, we 
estimate Model 5, which is the individual level wage equation given in Equation (1). The different specifications are summarized in Table 2.

Table 2: Different empirical specifications of wage equations

\begin{tabular}{|llll|}
\hline Model & $\begin{array}{l}\text { Level of } \\
\text { aggregation }\end{array}$ & $\begin{array}{l}\text { Variables from IAB } \\
\text { Establishment Panel }\end{array}$ & $\begin{array}{l}\text { Variables from employment } \\
\text { statistics }\end{array}$ \\
\hline 1 & Plant & $\bar{w}_{j t}, \bar{Z}_{1, j t}, Z_{2, j t}$ & \\
2 & Plant & $\bar{w}_{j t}, \bar{Z}_{1, j t}, Z_{2, j t}$ & $\bar{X}_{j t}$ \\
3 & Plant & $\bar{w}_{j t}, Z_{2, j t}$ & $\bar{X}_{j t}, \bar{Z}_{1, j t}$ \\
4 & Plant & $Z_{2, j t}$ & $\bar{w}_{j t}, \bar{X}_{j t}, \bar{Z}_{1, j t}$ \\
5 & Individual & $Z_{2, j(i t)}$ & $w_{i t}, X_{i t}, \bar{Z}_{1, j(i t)}$ \\
\hline
\end{tabular}

Note: All models include year dummies $(J)$.

The dependent variable in our investigation is the log of wages, taken from the IAB Establishment Panel in Models 1 to 3 and from the employment statistics in Models 4 and 5 . Whereas the IAB panel data just provide information on the total wage bill of an establishment, the information on individual earnings in the employment statistics is more detailed, but it refers only to the income subject to social security contributions (i.e. up to the contribution assessment ceiling of the social security system). To take account for this censoring, we apply a Tobit analysis when estimating Model 5. At the plant level (Models 1-4), we use OLS since the distribution of the average wages analyzed is not censored. ${ }^{5}$

In accordance with the extant literature, we will also investigate whether our findings differ between blue-collar workers and white-collar workers. Therefore, we re-estimate Models 4 and 5 separately for both types of employees. For Models 1 to 3 , we cannot distinguish between both groups of employees, since the IAB panel only contains information on the total wage bill within a plant.

The main focus of our analysis is on the influence of exports on wages. We can make use of two alternative indicators of exports: First, a dummy variable indicating whether or not a plant has any exports, and second the proportion of

\footnotetext{
5 A special case is Model 4 which uses information from the employment statistics, where the individual wages have been aggregated to the plant level. Only one plant in the regression sample employs solely workers with censored wages (and hence, only for this plant the average wage is censored). In other plants, some of the workers earn wages that are censored, so that the average reported wage is smaller than the average of the actual wages. However, we have ignored any (small) bias arising from this underreporting since the bias should be correlated with individual qualification for which we control in our estimations and since there is no clearcut truncation point which could be taken into account in the plant-level estimations.
} 
exports within total sales. In our observation period 1995 to 1997, 69\% of all plants in western German manufacturing were exporters (employing $92 \%$ of the workers in our sample) and the average export share of all plants was $23 \%$ (40\% when employment-weighted as in the Appendix). More information on these and on the other variables employed in our analysis can be found in an Appendix Table.

\section{EMPIRICAL RESULTS}

The results of our empirical investigations using pooled data for the period 1995 to 1997 are presented in Tables 3a (for specifications with the export dummy) and 3b (for the export share). ${ }^{6}$ In both cases we started with Model 1 and made only use of the information available from the IAB Establishment Panel, in such a way mimicking the traditional approach adopted by the studies listed in Table 1. As can be seen from the tables, these regressions are well determined, most of the coefficients estimated are highly significant and of the expected sign. While the impact of control variables needs not to be discussed in detail, it is interesting to see that the well-established firm size effect on wages shows up and that the composition of the work force plays an important role for the size of the wage bill.

\section{[Tables $3 a$ and $3 b$ near here]}

The principal result is that the estimated coefficient of the dummy variable indicating that a plant is an exporter is not significantly different from zero at any conventional error level, while the coefficient of exports measured as a proportion of total sales is positive and statistically significant. According to the results reported for Model 1 in Table 3b, an increase in the share of exports by ten percentage points raises the wage by some 0.7 percent. This result is in line with the findings reported by Bernard and Wagner (1997) in an earlier study using plant level data from official statistics for one of the western German federal states.

Subsequently, we included additional information from the employment statistics (Model 2) and we replaced those independent variables from the IAB panel for which (more precise) data from the employment statistics were available

6 We also ran cross-section estimations for each year (available from the authors upon request), the results of which are in accordance with those of the pooled estimations presented here. In all models, estimation of standard errors is not based on the assumption that observations within plants (and between years) are independent, i.e. we made use of the cluster (plant) option of Stata. All computations were done inside the German Federal Labor Services using Stata SE 8.2. 
(Model 3). In Model 4 even the dependent variable was replaced by the aggregated wage variable from the employment statistics. The results reported in Table 3a show that, like in Model 1, exporting per se does not have an impact on wages in Models 2 to 4 . Looking at Table $3 \mathrm{~b}$ we find that the positive effect of a higher share of exports in total sales reported for Model 1 vanishes when additional information on the quality of the workforce is added and when some firm characteristics are measured more precisely. Note that both the point estimates of the exports variable and the t-values decrease considerably from Model 1 to Model 4. This finding of no positive impact of a higher export share on wages contradicts the earlier findings for German plants mentioned above, and the results for many other countries summarized in Table 1.

In the next step of our empirical exercise we looked at blue-collar and white-collar workers separately. The reason for this is that Bernard and Wagner (1997) report in their study using plant level data that the positive exporter wage differential is almost exclusively driven by higher wages of white-collar workers. As has been explained in section 3 above, Models 1 to 3 cannot be estimated separately for blue-collar and white-collar workers because the IAB Establishment Panel does not report average wages for these groups of employees. For Model 4, the results shown in Tables $4 \mathrm{a}$ and $4 \mathrm{~b}$ point into the same direction as the earlier findings for Germany: While for white-collar workers both the estimated coefficient for the exporter dummy and for the share of exports in total sales is positive and statistically significant at a conventional level, this is not the case for blue-collar workers where exporting even seems to have a negative impact.

[Tables $4 \mathrm{a}$ and $4 \mathrm{~b}$ near here]

Our preferred specification making optimal use of all information available at the most disaggregated level possible is Model 5. The results from estimations with both variants of the exports variable for all workers, and for blue-collar and whitecollar workers separately, can be summarized in one sentence: Contrary to what has been argued based on findings from earlier studies using data at the plant level, there is no such thing as an exporter wage differential. None of the estimated coefficients reported in Tables $3 a$ to $4 b$ for the export variable in Model 5 is positive and statistically significant at the five percent level or better. 


\section{CONCLUSIONS}

The bottom line of the empirical exercise performed in this study is that in (western) Germany exporting firms do not pay higher wages, ceteris paribus. The exporter wage premia vanish if linked employer-employee data instead of plant level data are used to estimate the wage equations. This finding is fully in line with speculations by Robert Z. Lawrence when commenting on the pioneering paper by Bernard and Jensen (1995).

Our results imply that - at least for western Germany - some further questions related to the issue of exporter wage premia are no longer on the research agenda of the microeconometrics of exporting. These include the direction of causality (do exports cause higher wages, or vice versa?), the theoretical explanation (why do exporting firms pay premia to their workers?), and the policy implications (are jobs in exporting firms better jobs that should be protected and subsidized?). Evidently, our results have to be replicated with linked employer-employee data sets from other countries before they may be taken for granted. Hopefully, our analysis can provide a stimulus for those researchers that have access to such data sets to invest some time in solving the exporter wage premium puzzle with better data. 


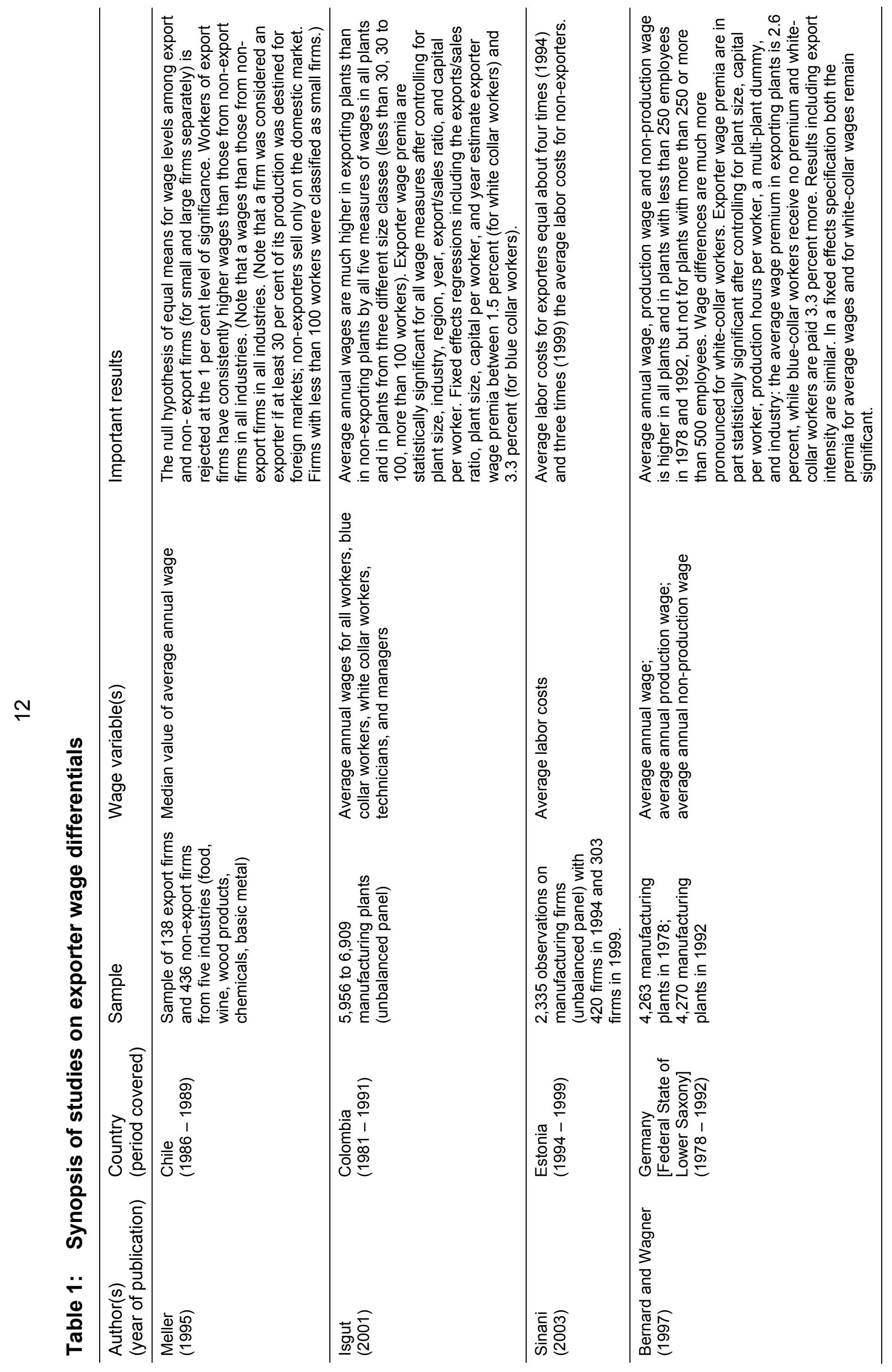




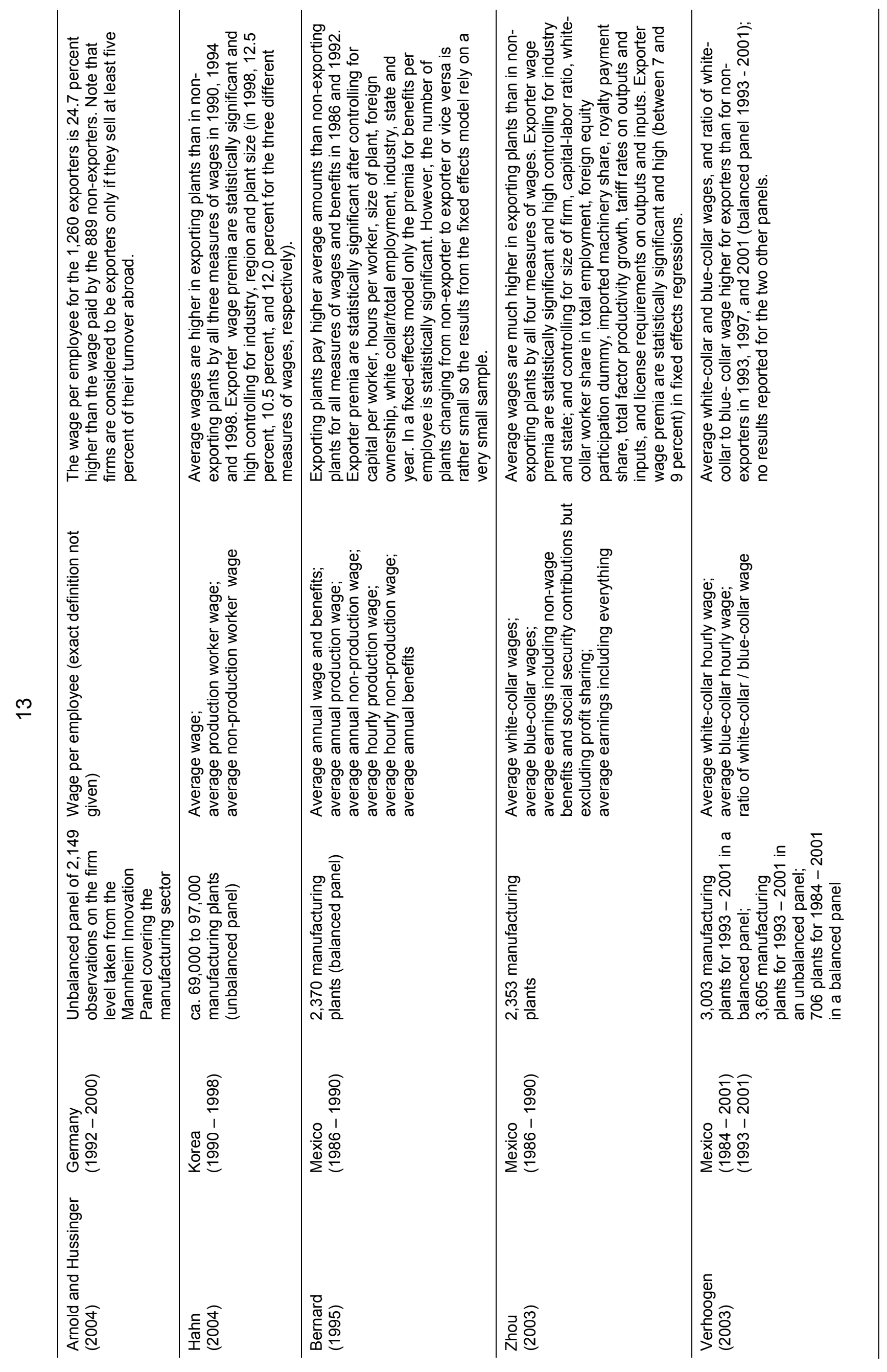




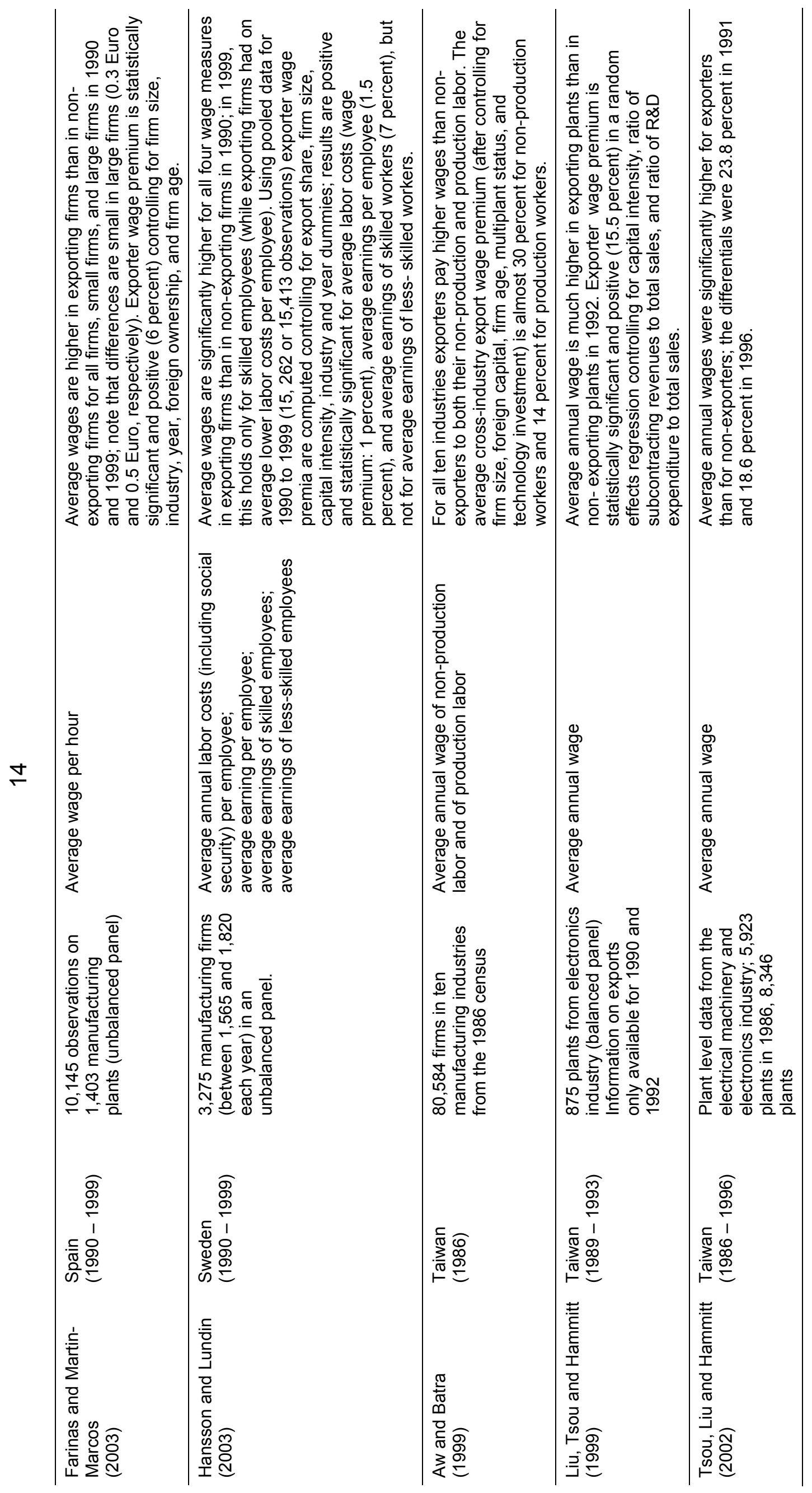




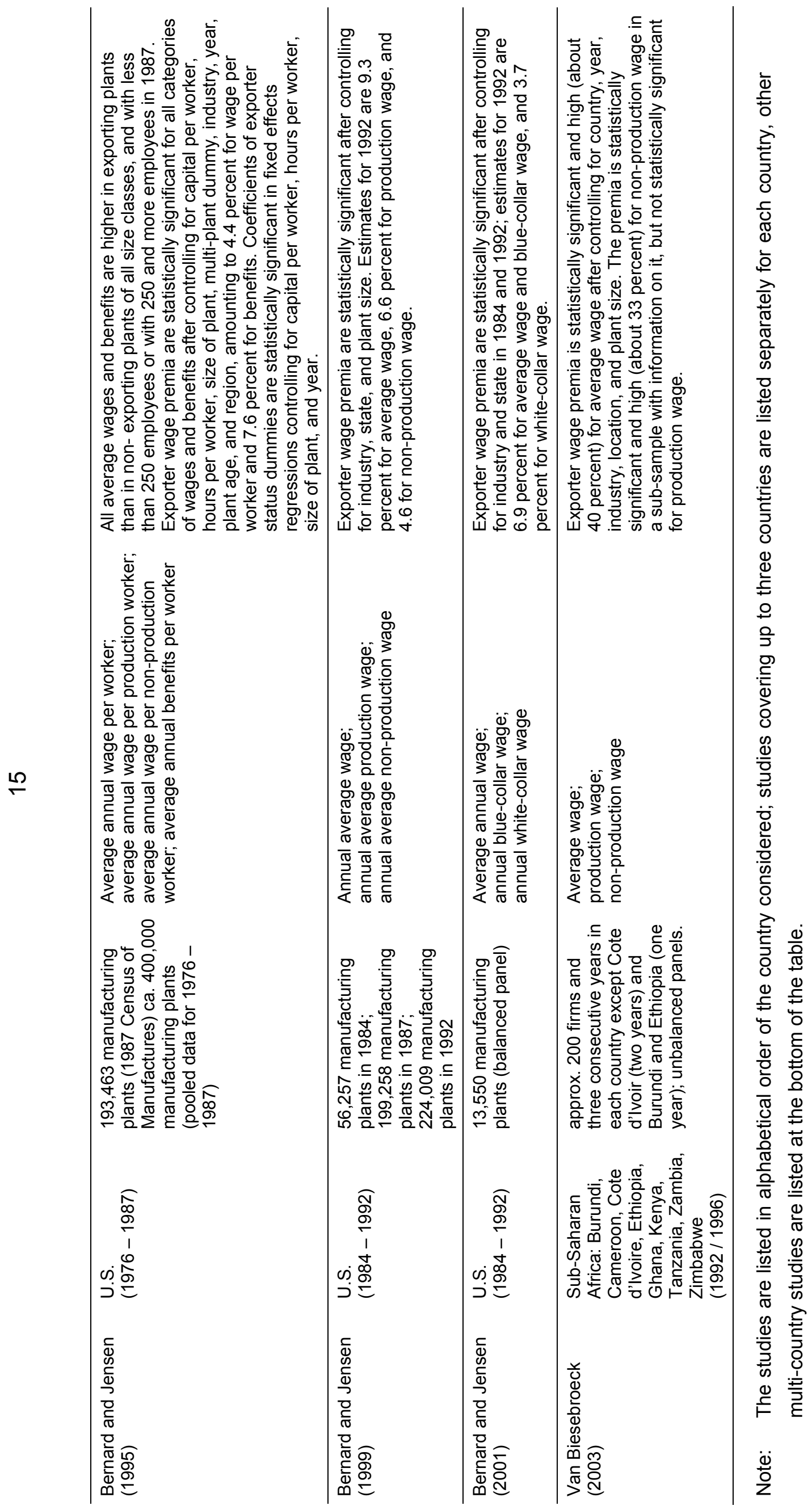


Table 3a: Wage Regressions, Manufacturing, Western Germany (Endogenous Variable: Log. Wage)

\begin{tabular}{|c|c|c|c|c|c|}
\hline \multirow[b]{2}{*}{ Variables } & \multicolumn{5}{|c|}{ Model } \\
\hline & 1 & 2 & 3 & 4 & 5 \\
\hline \multirow[t]{2}{*}{ Exporting plant ( $1=$ yes) } & 0.028 & 0.010 & -0.004 & 0.002 & -0.003 \\
\hline & [1.33] & {$[0.50]$} & [0.21] & {$[0.18]$} & {$[0.39]$} \\
\hline \multirow[t]{2}{*}{ Age of employee (years) } & & 0.022 & -0.027 & -0.006 & 0.023 \\
\hline & & {$[1.04]$} & [1.19] & {$[0.45]$} & {$[21.21]^{\star *}$} \\
\hline \multirow{2}{*}{$\begin{array}{l}\text { Age of employee squared } \\
\text { (divided by } 100 \text { ) }\end{array}$} & & -0.019 & 0.042 & 0.012 & -0.022 \\
\hline & & {$[0.71]$} & [1.48] & [0.66] & {$[18.71]^{\star *}$} \\
\hline \multirow[t]{2}{*}{ Gender $(1=$ female $)$} & & & & & -0.189 \\
\hline & & & & & {$[43.30]^{* *}$} \\
\hline \multirow{2}{*}{\multicolumn{6}{|c|}{$\begin{array}{l}\text { Professional status: (reference: } \\
\text { unskilled blue collar worker) }\end{array}$}} \\
\hline & & & & & \\
\hline \multirow{2}{*}{ Skilled blue collar worker } & & 0.092 & 0.111 & 0.102 & 0.063 \\
\hline & & {$[2.05]^{*}$} & {$[2.27]^{*}$} & {$[4.31]^{\star *}$} & {$[10.60]^{\star *}$} \\
\hline \multirow[t]{2}{*}{ Master craftsmen, foremen } & & 0.621 & 0.598 & 0.393 & 0.288 \\
\hline & & {$[4.60]^{\star *}$} & {$[3.87]^{\star *}$} & {$[5.26]^{\star *}$} & {$[16.90]^{\star *}$} \\
\hline \multirow{2}{*}{ White collar worker } & & 0.323 & 0.384 & 0.329 & 0.251 \\
\hline & & {$[5.28]^{\star *}$} & {$[6.21]^{\star *}$} & {$[9.19]^{* *}$} & {$[34.06]^{* *}$} \\
\hline \multirow[t]{2}{*}{ Part-time employee ( 1 = yes $)$} & & & & & -0.318 \\
\hline & & & & & {$[28.91]^{\star *}$} \\
\hline \multirow{2}{*}{ Married employee (1 = yes) } & & 0.041 & 0.065 & 0.028 & 0.019 \\
\hline & & {$[0.86]$} & [1.38] & [0.98] & {$[8.63]^{\star *}$} \\
\hline \multirow[t]{2}{*}{ Foreign employee ( 1 = yes $)$} & & & & & -0.020 \\
\hline & & & & & {$[5.76]^{\star *}$} \\
\hline \multirow{2}{*}{ Logarithm of establishment size } & 0.198 & 0.156 & 0.203 & 0.120 & 0.066 \\
\hline & {$[7.91]^{\star *}$} & {$[6.11]^{\star *}$} & {$[9.01]^{* *}$} & {$[8.90]^{* *}$} & {$[3.36]^{* *}$} \\
\hline \multirow{4}{*}{$\begin{array}{l}\text { Logarithm of establishment size } \\
\text { squared (divided by } 100 \text { ) } \\
\text { Proportions within total workforce } \\
\text { of plant: }\end{array}$} & -1.295 & -1.048 & -1.423 & -0.776 & -0.315 \\
\hline & {$[5.99]^{\star *}$} & {$[4.94]^{\star *}$} & {$[7.29]^{\star *}$} & {$[6.62]^{\star *}$} & [1.95] \\
\hline & & & & & \\
\hline & & & & & \\
\hline \multirow[t]{2}{*}{ Female workers } & -0.335 & -0.351 & -0.408 & -0.374 & -0.229 \\
\hline & {$[7.11]^{* *}$} & {$[7.37]^{\star \star}$} & {$[7.02]^{* *}$} & {$[10.85]^{\star *}$} & {$[9.16]^{* *}$} \\
\hline \multirow[t]{2}{*}{ Foreign workers } & & 0.024 & 0.053 & -0.021 & 0.054 \\
\hline & & {$[0.32]$} & {$[0.67]$} & {$[0.39]$} & [1.32] \\
\hline \multirow{2}{*}{$\begin{array}{l}\text { Workers with graduate } \\
\text { degree }\end{array}$} & 0.200 & 0.439 & 0.416 & 0.369 & 0.269 \\
\hline & {$[6.13]^{\star *}$} & {$[3.58]^{\star *}$} & {$[3.04]^{\star *}$} & {$[5.95]^{* *}$} & {$[6.85]^{\star *}$} \\
\hline \multirow[t]{2}{*}{ Part-time employees } & -0.598 & -0.629 & 0.046 & -0.402 & 0.180 \\
\hline & {$[6.44]^{* *}$} & {$[6.58]^{* *}$} & {$[0.41]$} & {$[5.43]^{\star *}$} & {$[2.59]^{\star *}$} \\
\hline
\end{tabular}




\begin{tabular}{|c|c|c|c|c|c|}
\hline \multicolumn{6}{|l|}{$\begin{array}{l}\text { Economic performance of } \\
\text { establishment (reference: } \\
\text { average performance) }\end{array}$} \\
\hline \multirow[t]{2}{*}{ Good } & 0.019 & 0.019 & 0.021 & 0.008 & 0.013 \\
\hline & [1.12] & {$[1.21]$} & {$[1.35]$} & [0.98] & {$[2.28]^{*}$} \\
\hline \multirow[t]{2}{*}{ Bad } & 0.017 & 0.002 & -0.003 & -0.009 & -0.003 \\
\hline & {$[1.31]$} & {$[0.12]$} & {$[0.23]$} & [1.49] & {$[0.42]$} \\
\hline Paid overtime work in & 0.048 & 0.047 & 0.035 & 0.032 & 0.023 \\
\hline establishment (1 = yes) & {$[2.95]^{\star *}$} & {$[3.03]^{* *}$} & {$[2.25]^{*}$} & {$[4.24]^{\star *}$} & {$[3.14]^{\star *}$} \\
\hline Shift work in establishment & -0.031 & 0.013 & 0.007 & 0.007 & 0.024 \\
\hline$(1=$ yes $)$ & {$[1.53]$} & {$[0.68]$} & {$[0.38]$} & {$[0.65]$} & {$[2.25]^{*}$} \\
\hline \multicolumn{6}{|l|}{$\begin{array}{l}\text { Collective agreement (reference: } \\
\text { no collective agreement) }\end{array}$} \\
\hline \multirow{2}{*}{ at sectoral level } & 0.029 & 0.025 & 0.039 & 0.033 & 0.029 \\
\hline & {$[1.08]$} & [0.98] & [1.49] & {$[2.19]^{*}$} & {$[1.15]$} \\
\hline \multirow[t]{2}{*}{ at firm level } & 0.044 & 0.053 & 0.059 & 0.019 & 0.048 \\
\hline & {$[1.40]$} & {$[1.74]$} & {$[1.85]$} & {$[1.10]$} & {$[1.81]$} \\
\hline Use of technology (index, $1=$ & -0.006 & -0.011 & -0.005 & -0.004 & -0.004 \\
\hline new, 5 = old $)$ & {$[0.70]$} & [1.38] & {$[0.61]$} & {$[0.84]$} & {$[0.90]$} \\
\hline Establishment formation in the & 0.011 & 0.005 & 0.019 & 0.004 & 0.003 \\
\hline last 5 years $(1=$ yes $)$ & {$[0.50]$} & {$[0.25]$} & {$[0.95]$} & {$[0.36]$} & {$[0.39]$} \\
\hline \multicolumn{6}{|l|}{$\begin{array}{l}\text { Year Dummies (reference: year } \\
=1995)\end{array}$} \\
\hline 1996 & $\begin{array}{l}0.025 \\
{[2.28]^{*}}\end{array}$ & $\begin{array}{l}0.019 \\
{[1.79]}\end{array}$ & $\begin{array}{l}0.025 \\
{[2.46]^{*}}\end{array}$ & $\begin{array}{l}0.028 \\
{[7.88]^{\star *}}\end{array}$ & $\begin{array}{l}0.020 \\
{[4.69]^{\star *}}\end{array}$ \\
\hline 1997 & $\begin{array}{l}0.025 \\
{[2.16]^{*}}\end{array}$ & $\begin{array}{l}0.018 \\
{[1.60]}\end{array}$ & $\begin{array}{l}0.026 \\
{[2.27]^{*}}\end{array}$ & $\begin{array}{l}0.031 \\
{[7.81]^{\star *}}\end{array}$ & $\begin{array}{l}0.029 \\
{[9.44]^{\star \star}}\end{array}$ \\
\hline $\begin{array}{l}98 \text { dummies for individual } \\
\text { profession }\end{array}$ & & & & & yes $^{* *}$ \\
\hline 9 federal state dummies & yes $^{* *}$ & yes $^{*}$ & yes & yes $^{* *}$ & yes $^{* *}$ \\
\hline 13 industry dummies & yes $^{* *}$ & yes $^{* *}$ & yes $^{* *}$ & yes $^{* *}$ & yes $^{* *}$ \\
\hline Constant & $\begin{array}{l}7.817 \\
{[84.89]^{* *}}\end{array}$ & $\begin{array}{l}7.284 \\
{[17.58]^{* *}}\end{array}$ & $\begin{array}{l}8.040 \\
{[18.48]^{* *}}\end{array}$ & $\begin{array}{l}9.296 \\
{[34.04]^{\star *}}\end{array}$ & $\begin{array}{l}8.934 \\
{[82.08]^{\star *}}\end{array}$ \\
\hline $\begin{array}{l}\text { Number of observations: total } \\
\text { (censored) }\end{array}$ & 2697 & 2697 & 2697 & 2948 & $\begin{array}{l}1,860,710 \\
(224,853)\end{array}$ \\
\hline Estimation Method & OLS & OLS & OLS & OLS & Tobit \\
\hline $\mathrm{R}^{2}$ & 0.492 & 0.535 & 0.532 & 0.781 & \\
\hline
\end{tabular}

Source:LIAB 1995-1997. Absolute values of t-statistics in brackets. ${ }^{* *} /{ }^{*}$ denote significance at the $1 \% / 5 \%$ level, respectively. 
Table 3b: Wage Regressions, Manufacturing, Western Germany (Endogenous Variable: Log. Wage)

\begin{tabular}{|c|c|c|c|c|c|}
\hline \multirow[b]{2}{*}{ Variables } & \multicolumn{5}{|c|}{ Model } \\
\hline & 1 & 2 & 3 & 4 & 5 \\
\hline Exports (proportion of total sales) & $\begin{array}{l}0.073 \\
{[2.43]^{*}}\end{array}$ & $\begin{array}{l}0.036 \\
{[1.26]}\end{array}$ & $\begin{array}{l}0.022 \\
{[0.76]}\end{array}$ & $\begin{array}{l}0.006 \\
\Gamma 0.38]\end{array}$ & $\begin{array}{l}0.023 \\
11731\end{array}$ \\
\hline Age of employee (years) & & $\begin{array}{l}0.023 \\
{[1.06]}\end{array}$ & $\begin{array}{l}-0.027 \\
{[1.17]}\end{array}$ & $\begin{array}{l}-0.006 \\
{[0.44]}\end{array}$ & $\begin{array}{l}0.023 \\
{[21.31]^{\star \star}}\end{array}$ \\
\hline $\begin{array}{l}\text { Age of employee squared } \\
\text { (divided by } 100 \text { ) }\end{array}$ & & $\begin{array}{l}-0.020 \\
{[0.74]}\end{array}$ & $\begin{array}{l}0.042 \\
{[1.46]}\end{array}$ & $\begin{array}{l}0.012 \\
{[0.65]}\end{array}$ & $\begin{array}{l}-0.022 \\
{[18.83]^{\star \star}}\end{array}$ \\
\hline Gender ( 1 = female $)$ & & & & & $\begin{array}{l}-0.189 \\
{[43.47]^{* *}}\end{array}$ \\
\hline $\begin{array}{l}\text { Professional status: (reference: } \\
\text { unskilled blue collar worker) }\end{array}$ & & & & & \\
\hline Skilled blue collar worker & & $\begin{array}{l}0.091 \\
{[2.01]^{*}}\end{array}$ & $\begin{array}{l}0.111 \\
{[2.27]^{*}}\end{array}$ & $\begin{array}{l}0.101 \\
{[4.28]^{* *}}\end{array}$ & $\begin{array}{l}0.063 \\
{[10.51]^{\star *}}\end{array}$ \\
\hline Master craftsmen, foremen & & $\begin{array}{l}0.620 \\
{[4.59]^{\star *}}\end{array}$ & $\begin{array}{l}0.597 \\
{[3.86]^{* *}}\end{array}$ & $\begin{array}{l}0.393 \\
{[5.26]^{* *}}\end{array}$ & $\begin{array}{l}0.288 \\
{[16.93]^{\star *}}\end{array}$ \\
\hline White collar worker & & $\begin{array}{l}0.321 \\
{[5.25]^{\star *}}\end{array}$ & $\begin{array}{l}0.383 \\
{[6.21]^{\star *}}\end{array}$ & $\begin{array}{l}0.328 \\
{[9.18]^{\star *}}\end{array}$ & $\begin{array}{l}0.251 \\
{[33.96]^{\star \star}}\end{array}$ \\
\hline Part-time employee ( 1 = yes) & & & & & $\begin{array}{l}-0.318 \\
{[28.93]^{\star *}}\end{array}$ \\
\hline Married employee (1 = yes) & & $\begin{array}{l}0.041 \\
{[0.84]}\end{array}$ & $\begin{array}{l}0.064 \\
{[1.37]}\end{array}$ & $\begin{array}{l}0.028 \\
{[0.98]}\end{array}$ & $\begin{array}{l}0.019 \\
{[8.35]^{\star \star}}\end{array}$ \\
\hline Foreign employee (1 = yes) & & & & & $\begin{array}{l}-0.020 \\
{[5.75]^{\star *}}\end{array}$ \\
\hline Logarithm of establishment size & $\begin{array}{l}0.203 \\
{[8.51]^{\star *}}\end{array}$ & $\begin{array}{l}0.157 \\
{[6.43]^{* *}}\end{array}$ & $\begin{array}{l}0.202 \\
{[9.30]^{* *}}\end{array}$ & $\begin{array}{l}0.120 \\
{[9.26]^{* *}}\end{array}$ & $\begin{array}{l}0.066 \\
{[3.44]^{* *}}\end{array}$ \\
\hline $\begin{array}{l}\text { Logarithm of establishment size } \\
\text { squared (divided by } 100 \text { ) }\end{array}$ & $\begin{array}{l}-1.353 \\
{[6.48]^{* *}}\end{array}$ & $\begin{array}{l}-1.068 \\
{[5.19]^{\star *}}\end{array}$ & $\begin{array}{l}-1.421 \\
{[7.45]^{* *}}\end{array}$ & $\begin{array}{l}-0.779 \\
{[6.83]^{* *}}\end{array}$ & $\begin{array}{l}-0.324 \\
{[2.03]^{*}}\end{array}$ \\
\hline $\begin{array}{l}\text { Proportions within total workforce } \\
\text { of plant: }\end{array}$ & & & & & \\
\hline Female workers & $\begin{array}{l}-0.337 \\
{[7.13]^{\star *}}\end{array}$ & $\begin{array}{l}-0.352 \\
{[7.40]^{* *}}\end{array}$ & $\begin{array}{l}-0.409 \\
{[7.06]^{* *}}\end{array}$ & $\begin{array}{l}-0.374 \\
{[10.89]^{\star *}}\end{array}$ & $\begin{array}{l}-0.229 \\
{[9.24]^{* *}}\end{array}$ \\
\hline Foreign workers & & $\begin{array}{l}0.021 \\
{[0.28]}\end{array}$ & $\begin{array}{l}0.050 \\
{[0.64]}\end{array}$ & $\begin{array}{l}-0.021 \\
{[0.39]}\end{array}$ & $\begin{array}{l}0.050 \\
{[1.25]}\end{array}$ \\
\hline $\begin{array}{l}\text { Workers with graduate } \\
\text { degree }\end{array}$ & $\begin{array}{l}0.194 \\
{[5.98]^{\star *}}\end{array}$ & $\begin{array}{l}0.430 \\
{[3.50]^{* *}}\end{array}$ & $\begin{array}{l}0.407 \\
{[2.97]^{* *}}\end{array}$ & $\begin{array}{l}0.367 \\
{[5.96]^{* *}}\end{array}$ & $\begin{array}{l}0.260 \\
{[6.67]^{* *}}\end{array}$ \\
\hline Part-time employees & $\begin{array}{l}-0.599 \\
{[6.51]^{\star *}}\end{array}$ & $\begin{array}{l}-0.628 \\
{[6.62]^{\star *}}\end{array}$ & $\begin{array}{l}0.046 \\
{[0.42]}\end{array}$ & $\begin{array}{l}-0.402 \\
{[5.44]^{* *}}\end{array}$ & $\begin{array}{l}0.182 \\
{[2.61]^{\star *}}\end{array}$ \\
\hline
\end{tabular}




\begin{tabular}{|c|c|c|c|c|c|}
\hline \multicolumn{6}{|l|}{$\begin{array}{l}\text { Economic performance of } \\
\text { establishment (reference: } \\
\text { average performance) }\end{array}$} \\
\hline \multirow[t]{2}{*}{ Good } & 0.016 & 0.017 & 0.020 & 0.008 & 0.012 \\
\hline & {$[0.95]$} & {$[1.12]$} & {$[1.30]$} & [0.95] & {$[2.13]^{*}$} \\
\hline \multirow[t]{2}{*}{ Bad } & 0.016 & 0.001 & -0.003 & -0.009 & -0.002 \\
\hline & [1.23] & {$[0.09]$} & {$[0.23]$} & {$[1.50]$} & {$[0.35]$} \\
\hline Paid overtime work in & 0.049 & 0.047 & 0.035 & 0.032 & 0.023 \\
\hline establishment (1 = yes) & {$[3.03]^{* *}$} & {$[3.07]^{\star *}$} & {$[2.26]^{*}$} & {$[4.27]^{* *}$} & {$[3.21]^{\star *}$} \\
\hline Shift work in establishment & -0.034 & 0.011 & 0.005 & 0.007 & 0.021 \\
\hline$(1=$ yes $)$ & {$[1.69]$} & {$[0.56]$} & {$[0.24]$} & [0.62] & {$[1.97]^{*}$} \\
\hline \multicolumn{6}{|l|}{$\begin{array}{l}\text { Collective agreement (reference: } \\
\text { no collective agreement) }\end{array}$} \\
\hline \multirow[t]{2}{*}{ at sectoral level } & 0.029 & 0.026 & 0.040 & 0.033 & 0.029 \\
\hline & [1.10] & {$[0.99]$} & [1.53] & {$[2.19]^{*}$} & [1.19] \\
\hline \multirow[t]{2}{*}{ at firm level } & 0.047 & 0.054 & 0.060 & 0.019 & 0.049 \\
\hline & {$[1.50]$} & {$[1.78]$} & {$[1.86]$} & {$[1.11]$} & {$[1.88]$} \\
\hline Use of technology (index, & -0.006 & -0.011 & -0.005 & -0.004 & -0.004 \\
\hline $1=$ new, $5=$ old $)$ & {$[0.77]$} & {$[1.43]$} & {$[0.66]$} & {$[0.85]$} & {$[0.89]$} \\
\hline Establishment formation in & 0.011 & 0.006 & 0.020 & 0.004 & 0.004 \\
\hline the last 5 years $(1=$ yes $)$ & [0.53] & {$[0.28]$} & {$[0.98]$} & {$[0.36]$} & {$[0.46]$} \\
\hline \multirow{2}{*}{\multicolumn{6}{|c|}{$\begin{array}{l}\text { Year Dummies (reference: year = } \\
1995 \text { ) }\end{array}$}} \\
\hline & & & & & \\
\hline \multirow[t]{2}{*}{1996} & 0.024 & 0.018 & 0.025 & 0.028 & 0.020 \\
\hline & {$[2.20]^{*}$} & {$[1.75]$} & {$[2.46]^{*}$} & {$[7.90]^{* *}$} & {$[4.73]^{\star *}$} \\
\hline \multirow[t]{2}{*}{1997} & 0.025 & 0.018 & 0.025 & 0.031 & 0.028 \\
\hline & {$[2.16]^{*}$} & {$[1.58]$} & {$[2.23]^{*}$} & {$[7.78]^{\star *}$} & {$[9.14]^{\star *}$} \\
\hline $\begin{array}{l}98 \text { dummies for individual } \\
\text { profession }\end{array}$ & & & & & yes $^{* *}$ \\
\hline 9 federal state dummies & yes $^{* *}$ & yes $^{*}$ & yes & yes $^{* *}$ & yes $^{* *}$ \\
\hline 13 industry dummies & yes $^{* *}$ & yes $^{* *}$ & yes $^{* *}$ & yes $^{* *}$ & yes $^{* *}$ \\
\hline Constant & 7.811 & 7.273 & 8.035 & 9.294 & 8.927 \\
\hline & {$[85.06]^{* *}$} & {$[17.62]^{\star *}$} & {$[18.46]^{* *}$} & {$[33.98]^{\star *}$} & {$[82.49]^{* *}$} \\
\hline $\begin{array}{l}\text { Number of observations: total } \\
\text { (censored) }\end{array}$ & 2697 & 2697 & 2697 & 2948 & $\begin{array}{l}1,860,710 \\
(224,853)\end{array}$ \\
\hline Estimation Method & OLS & OLS & OLS & OLS & Tobit \\
\hline $\mathrm{R}^{2}$ & 0.493 & 0.536 & 0.532 & 0.781 & \\
\hline
\end{tabular}

Source: LIAB 1995-1997. Absolute values of t-statistics in brackets. ${ }^{* *} /{ }^{*}$ denote significance at the $1 \% / 5 \%$ level, respectively. 
Table 4a: Wage Regressions; Separately for Blue-collar Workers (BC) and White-Collar Workers (WC), Manufacturing, Western Germany (Endogenous Variable: Log. Wage)

\begin{tabular}{|c|c|c|c|c|}
\hline \multirow[b]{2}{*}{ Variables } & \multicolumn{2}{|c|}{ Model 4} & \multicolumn{2}{|c|}{ Model 5} \\
\hline & $\mathrm{BC}$ & WC & $\mathrm{BC}$ & WC \\
\hline \multirow[t]{2}{*}{ Exporting Plant (1 = yes) } & -0.040 & 0.040 & -0.009 & 0.005 \\
\hline & {$[3.43]^{* *}$} & {$[2.56]^{*}$} & {$[1.00]$} & {$[0.60]$} \\
\hline \multirow[t]{2}{*}{ Age of employee (years) } & 0.001 & -0.016 & 0.017 & 0.048 \\
\hline & {$[0.04]$} & [0.68] & {$[17.28]^{\star \star}$} & {$[47.04]^{* *}$} \\
\hline \multirow{2}{*}{$\begin{array}{l}\text { Age of employee squared (divided by } \\
100 \text { ) }\end{array}$} & 0.006 & 0.032 & -0.018 & -0.047 \\
\hline & {$[0.26]$} & [1.13] & {$[15.24]^{\star \star}$} & {$[40.38]^{\star *}$} \\
\hline \multirow[t]{2}{*}{ Gender $(1=$ female $)$} & & & -0.152 & -0.194 \\
\hline & & & {$[31.71]^{\star *}$} & {$[23.50]^{\star *}$} \\
\hline \multicolumn{5}{|l|}{$\begin{array}{l}\text { Professional status: (reference: } \\
\text { unskilled blue collar worker) }\end{array}$} \\
\hline \multirow[t]{2}{*}{ Skilled blue collar worker } & 0.083 & & 0.066 & \\
\hline & {$[3.28]^{\star *}$} & & {$[10.79]^{\star *}$} & \\
\hline \multirow[t]{2}{*}{ Master craftsmen, foremen } & 0.52 & & 0.318 & \\
\hline & {$[5.92]^{\star *}$} & & {$[10.89]^{* *}$} & \\
\hline \multirow[t]{2}{*}{ Married employee (1 = yes) } & 0.035 & 0.013 & 0.02 & 0.021 \\
\hline & {$[1.26]$} & {$[0.35]$} & {$[7.99]^{\star *}$} & {$[8.66]^{* *}$} \\
\hline \multirow[t]{2}{*}{ Foreign employee (1 = yes) } & & & -0.018 & -0.014 \\
\hline & & & {$[5.60]^{* *}$} & {$[3.43]^{* *}$} \\
\hline \multirow[t]{2}{*}{ Logarithm of establishment size } & 0.092 & 0.180 & 0.046 & 0.104 \\
\hline & {$[5.89]^{\star *}$} & {$[8.93]^{* *}$} & [1.88] & {$[5.69]^{\star *}$} \\
\hline Logarithm of establishment size & -0.542 & -1.202 & -0.165 & -0.585 \\
\hline squared (divided by 100) & {$[4.05]^{\star *}$} & {$[7.16]^{* *}$} & {$[0.80]$} & {$[4.39]^{* *}$} \\
\hline \multicolumn{5}{|l|}{$\begin{array}{l}\text { Proportions within total workforce of } \\
\text { plant: }\end{array}$} \\
\hline \multirow[t]{2}{*}{ Female workers } & -0.333 & -0.265 & -0.249 & -0.071 \\
\hline & {$[11.06]^{\star *}$} & {$[6.25]^{* *}$} & {$[10.10]^{\star \star}$} & {$[2.51]^{*}$} \\
\hline \multirow[t]{2}{*}{ Foreign workers } & -0.085 & 0.049 & -0.009 & 0.119 \\
\hline & {$[2.22]^{*}$} & {$[0.88]$} & {$[0.19]$} & {$[2.54]^{*}$} \\
\hline Workers with graduate & 0.361 & 0.347 & 0.249 & 0.272 \\
\hline Degree & {$[5.94]^{\star *}$} & {$[5.70]^{* *}$} & {$[4.33]^{\star *}$} & {$[6.53]^{* *}$} \\
\hline \multicolumn{5}{|l|}{$\begin{array}{l}\text { Economic performance of } \\
\text { establishment (reference: average } \\
\text { performance) }\end{array}$} \\
\hline \multirow[t]{2}{*}{ Good } & 0.011 & 0.014 & 0.012 & 0.013 \\
\hline & {$[1.28]$} & [1.36] & [1.93] & {$[2.22]^{*}$} \\
\hline \multirow[t]{2}{*}{ Bad } & -0.005 & -0.003 & -0.001 & -0.002 \\
\hline & {$[0.79]$} & {$[0.45]$} & {$[0.08]$} & {$[0.41]$} \\
\hline
\end{tabular}




\begin{tabular}{|c|c|c|c|c|}
\hline $\begin{array}{l}\text { Paid overtime work in establishment } \\
(1=\text { yes })\end{array}$ & $\begin{array}{l}0.04 \\
{[5.15]^{\star *}}\end{array}$ & $\begin{array}{l}0.024 \\
{[2.19]^{*}}\end{array}$ & $\begin{array}{l}0.028 \\
{[3.16]^{\star *}}\end{array}$ & $\begin{array}{l}0.017 \\
{[2.39]^{*}}\end{array}$ \\
\hline Shift work in establishment & -0.005 & 0.032 & 0.027 & 0.012 \\
\hline$(1=$ yes $)$ & {$[0.46]$} & {$[2.42]^{*}$} & {$[2.19]^{*}$} & {$[1.02]$} \\
\hline \multicolumn{5}{|l|}{$\begin{array}{l}\text { Collective agreement (reference: no } \\
\text { collective agreement) }\end{array}$} \\
\hline \multirow[t]{2}{*}{ at sectoral level } & 0.019 & 0.013 & 0.041 & 0.007 \\
\hline & [1.22] & {$[0.67]$} & [1.19] & {$[0.42]$} \\
\hline \multirow[t]{2}{*}{ at firm level } & -0.007 & 0.029 & 0.056 & 0.033 \\
\hline & {$[0.40]$} & [1.37] & {$[1.61]$} & [1.81] \\
\hline Use of technology (index, 1= new, $5=$ & -0.007 & 0.000 & -0.003 & -0.005 \\
\hline old) & [1.60] & {$[0.06]$} & {$[0.51]$} & [1.16] \\
\hline Establishment formation in the last 5 & 0.006 & 0.025 & 0.006 & -0.003 \\
\hline years $(1=$ yes $)$ & [0.53] & [1.71] & {$[0.56]$} & {$[0.40]$} \\
\hline \multicolumn{5}{|l|}{$\begin{array}{l}\text { Year Dummies (reference: year = } \\
\text { 1995) }\end{array}$} \\
\hline \multirow[t]{2}{*}{1996} & 0.022 & 0.025 & 0.020 & 0.025 \\
\hline & {$[6.39]^{* *}$} & {$[5.75]^{\star *}$} & {$[4.06]^{* *}$} & {$[6.87]^{* *}$} \\
\hline \multirow[t]{2}{*}{1997} & 0.028 & 0.034 & 0.028 & 0.036 \\
\hline & {$[7.34]^{\star \star}$} & {$[6.45]^{\star \star}$} & {$[7.82]^{\star *}$} & {$[10.26]^{\star *}$} \\
\hline 98 dummies for individual profession & & & yes $^{* *}$ & yes $^{* *}$ \\
\hline 9 federal state dummies & yes $^{* *}$ & yes $^{* *}$ & yes $^{* *}$ & yes $^{* *}$ \\
\hline 13 industry dummies & yes $^{* *}$ & yes $^{* *}$ & yes $^{* *}$ & yes $^{* *}$ \\
\hline \multirow[t]{2}{*}{ Constant } & 9.192 & 9.394 & 8.968 & 9.373 \\
\hline & {$[30.84]^{* *}$} & {$[21.28]^{* *}$} & {$[106.97]^{\star *}$} & {$[]$.} \\
\hline Number of observations: total & & & 1198254 & 598968 \\
\hline (censored) & 2853 & 2725 & $(20,326)$ & $(203,898)$ \\
\hline Estimation method & OLS & OLS & Tobit & Tobit \\
\hline $\mathrm{R}^{2}$ & 0.614 & 0.646 & & \\
\hline
\end{tabular}

Source: LIAB 1995-1997. Absolute values of t-statistics in brackets. **/ * denote significance at the $1 \% / 5 \%$ level, respectively. 
Table 4b: Wage Regressions; Separately for Blue-Collar Workers (BC) and White-Collar Workers (WC), Manufacturing, Western Germany (Endogenous Variable: Log. Wage)

\begin{tabular}{|c|c|c|c|c|}
\hline \multirow[b]{2}{*}{ Variables } & \multicolumn{2}{|c|}{ Model 4} & \multicolumn{2}{|c|}{ Model 5} \\
\hline & $\mathrm{BC}$ & WC & $\mathrm{BC}$ & WC \\
\hline \multirow[t]{2}{*}{ Exports (Proportion of total sales) } & -0.003 & 0.034 & 0.032 & 0.006 \\
\hline & {$[0.21]$} & {$[2.01]^{*}$} & [1.84] & {$[0.50]$} \\
\hline \multirow[t]{2}{*}{ Age of employee (years) } & 0.001 & -0.015 & 0.017 & 0.048 \\
\hline & {$[0.08]$} & {$[0.64]$} & {$[17.51]^{\star \star}$} & {$[46.99]^{\star *}$} \\
\hline \multirow{2}{*}{$\begin{array}{l}\text { Age of employee squared (divided } \\
\text { by } 100 \text { ) }\end{array}$} & 0.005 & 0.031 & -0.018 & -0.047 \\
\hline & {$[0.22]$} & {$[1.10]$} & {$[15.48]^{\star *}$} & {$[40.31]^{\star *}$} \\
\hline \multirow[t]{2}{*}{ Gender $(1=$ female $)$} & & & -0.152 & -0.194 \\
\hline & & & {$[31.94]^{\star *}$} & {$[23.47]^{\star *}$} \\
\hline \multicolumn{5}{|l|}{$\begin{array}{l}\text { Professional status: (reference: } \\
\text { unskilled blue collar worker) }\end{array}$} \\
\hline \multirow[t]{2}{*}{ Skilled blue collar worker } & 0.088 & & 0.065 & \\
\hline & {$[3.47]^{* *}$} & & {$[10.66]^{* *}$} & \\
\hline \multirow[t]{2}{*}{ Master craftsmen, foremen } & 0.517 & & 0.318 & \\
\hline & {$[5.84]^{* *}$} & & {$[10.95]^{\star *}$} & \\
\hline \multirow[t]{2}{*}{ Married employee (1 = yes) } & 0.035 & 0.012 & 0.020 & 0.021 \\
\hline & [1.23] & {$[0.32]$} & {$[7.58]^{\star *}$} & {$[8.61]^{\star *}$} \\
\hline \multirow[t]{2}{*}{ Foreign employee ( 1 = yes) } & & & -0.018 & -0.014 \\
\hline & & & {$[5.61]^{\star *}$} & {$[3.47]^{\star *}$} \\
\hline \multirow[t]{2}{*}{ Logarithm of establishment size } & 0.084 & 0.188 & 0.046 & 0.105 \\
\hline & {$[5.58]^{\star *}$} & {$[9.60]^{\star *}$} & [1.89] & {$[5.75]^{\star *}$} \\
\hline Logarithm of establishment size & -0.493 & -1.261 & -0.171 & -0.593 \\
\hline squared (divided by 100 ) & {$[3.78]^{\star *}$} & {$[7.68]^{* *}$} & {$[0.83]$} & {$[4.45]^{\star *}$} \\
\hline \multicolumn{5}{|l|}{$\begin{array}{l}\text { Proportions within total workforce } \\
\text { of plant: }\end{array}$} \\
\hline \multirow[t]{2}{*}{ Female workers } & -0.337 & -0.262 & -0.25 & -0.071 \\
\hline & {$[11.00]^{* *}$} & {$[6.20]^{* *}$} & {$[10.25]^{* *}$} & {$[2.50]^{*}$} \\
\hline \multirow[t]{2}{*}{ Foreign workers } & -0.09 & 0.053 & -0.013 & 0.119 \\
\hline & {$[2.33]^{*}$} & [0.94] & {$[0.30]$} & {$[2.58]^{* * *}$} \\
\hline Workers with graduate & 0.349 & 0.351 & 0.239 & 0.27 \\
\hline degree & {$[5.75]^{\star *}$} & {$[5.67]^{\star *}$} & {$[4.21]^{* *}$} & {$[6.54]^{\star *}$} \\
\hline \multicolumn{5}{|l|}{$\begin{array}{l}\text { Economic performance of } \\
\text { establishment (reference: average } \\
\text { performance) }\end{array}$} \\
\hline \multirow[t]{2}{*}{ Good } & & 0.013 & 0.011 & 0.013 \\
\hline & $0.01[1.26]$ & [1.25] & [1.73] & {$[2.18]^{*}$} \\
\hline \multirow[t]{2}{*}{ Bad } & -0.004 & -0.004 & 0 & -0.002 \\
\hline & {$[0.70]$} & {$[0.58]$} & {$[0.02]$} & {$[0.42]$} \\
\hline
\end{tabular}




\begin{tabular}{|c|c|c|c|c|}
\hline $\begin{array}{l}\text { Paid overtime work in } \\
\text { establishment }(1=\text { yes })\end{array}$ & $\begin{array}{l}0.039 \\
{[4.96]^{* *}}\end{array}$ & $\begin{array}{l}0.025 \\
{[2.28]^{*}}\end{array}$ & $\begin{array}{l}0.028 \\
{[3.23]^{\star *}}\end{array}$ & $\begin{array}{l}0.017 \\
{[2.39]^{\star}}\end{array}$ \\
\hline Shift work in establishment & -0.01 & 0.034 & 0.021 & 0.012 \\
\hline$(1=$ yes $)$ & {$[0.82]$} & {$[2.52]^{*}$} & {$[1.81]$} & {$[1.00]$} \\
\hline \multicolumn{5}{|l|}{$\begin{array}{l}\text { Collective agreement (reference: } \\
\text { no collective agreement) }\end{array}$} \\
\hline \multirow[t]{2}{*}{ at sectoral level } & 0.021 & 0.011 & 0.041 & 0.007 \\
\hline & [1.38] & {$[0.57]$} & [1.22] & {$[0.42]$} \\
\hline \multirow[t]{2}{*}{ at firm level } & -0.008 & 0.032 & 0.057 & 0.034 \\
\hline & {$[0.47]$} & [1.48] & {$[1.67]$} & [1.83] \\
\hline Use of technology (index, 1= new, & -0.007 & 0.000 & -0.002 & -0.005 \\
\hline $5=$ old $)$ & [1.67] & {$[0.07]$} & {$[0.48]$} & [1.13] \\
\hline Establishment formation in the last & 0.007 & 0.024 & 0.007 & -0.003 \\
\hline 5 years $(1=$ yes $)$ & [0.62] & [1.67] & {$[0.65]$} & {$[0.38]$} \\
\hline \multicolumn{5}{|l|}{$\begin{array}{l}\text { Year Dummies (reference: year = } \\
1995 \text { ) }\end{array}$} \\
\hline 1996 & $\begin{array}{l}0.022 \\
{[6.56]^{\star \star}}\end{array}$ & $\begin{array}{l}0.025 \\
{[5.62]^{\star *}}\end{array}$ & $\begin{array}{l}0.02 \\
{[4.05]^{\star *}}\end{array}$ & $\begin{array}{l}0.025 \\
{[6.90]^{* *}}\end{array}$ \\
\hline 1997 & $\begin{array}{l}0.027 \\
{[6.89]^{\star *}}\end{array}$ & $\begin{array}{l}0.035 \\
{[6.54]^{\star *}}\end{array}$ & $\begin{array}{l}0.026 \\
{[7.39]^{\star \star}}\end{array}$ & $\begin{array}{l}0.036 \\
{[10.29]^{\star *}}\end{array}$ \\
\hline $\begin{array}{l}98 \text { dummies for individual } \\
\text { profession }\end{array}$ & & & yes $^{* *}$ & yes $^{* *}$ \\
\hline 9 federal state dummies & yes $^{\star *}$ & yes $^{* *}$ & yes $^{* *}$ & yes $^{* *}$ \\
\hline 13 industry dummies & yes ${ }^{* *}$ & yes ${ }^{\star *}$ & yes ${ }^{* *}$ & yes $^{* *}$ \\
\hline \multirow[t]{2}{*}{ Constant } & 9.191 & 9.366 & 8.957 & 9.371 \\
\hline & {$[30.78]^{* *}$} & {$[21.17]^{\star *}$} & {$[106.65]^{* *}$} & {$[]$.} \\
\hline $\begin{array}{l}\text { Number of observations: total } \\
\text { (censored) }\end{array}$ & 2853 & 2725 & $\begin{array}{l}1198254 \\
(20,326)\end{array}$ & $\begin{array}{l}598968 \\
(203,898)\end{array}$ \\
\hline Estimation Method & OLS & OLS & Tobit & Tobit \\
\hline $\mathrm{R}^{2}$ & 0.610 & 0.644 & & \\
\hline
\end{tabular}

Source: LIAB 1995-1997. Absolute values of t-statistics in brackets. **/ * denote significance at the $1 \% / 5 \%$ level, respectively. 
Appendix 1: Descriptive Statistics; Regression Sample (Individual Level), Manufacturing, Western Germany

\begin{tabular}{|c|c|c|c|c|c|c|}
\hline \multirow[b]{2}{*}{ Variables } & \multicolumn{2}{|c|}{ All } & \multicolumn{2}{|c|}{$\begin{array}{l}\text { Blue Collar } \\
\text { Workers }\end{array}$} & \multicolumn{2}{|c|}{$\begin{array}{l}\text { White Collar } \\
\text { Workers }\end{array}$} \\
\hline & mean & s.d. & mean & s.d. & mean & s.d. \\
\hline $\begin{array}{l}\text { Logarithm of daily wage } \\
\text { (in Pfennigen) }\end{array}$ & 9.775 & 0.293 & 9.694 & 0.223 & 9.995 & 0.235 \\
\hline $\begin{array}{l}\text { Exports (proportion of total } \\
\text { sales) }\end{array}$ & 0.396 & 0.238 & 0.392 & 0.232 & 0.407 & 0.251 \\
\hline Exporting plant ( 1 = yes) & 0.921 & 0.270 & 0.926 & 0.261 & 0.910 & 0.286 \\
\hline Age of employee (years) & 40.160 & 10.296 & 39.345 & 10.351 & 41.621 & 10.102 \\
\hline $\begin{array}{l}\text { Age of employee squared } \\
\text { (divided by } 100 \text { ) }\end{array}$ & 17.188 & 8.486 & 16.551 & 8.406 & 18.343 & 8.565 \\
\hline $\begin{array}{l}\text { Gender }(1=\text { female) } \\
\text { Professional status: } \\
\text { (reference: unskilled blue } \\
\text { collar worker) }\end{array}$ & 0.197 & 0.397 & 0.139 & 0.346 & 0.238 & 0.426 \\
\hline Skilled blue collar worker & 0.281 & 0.449 & 0.436 & 0.496 & 0.000 & 0.000 \\
\hline $\begin{array}{l}\text { Master craftsmen, } \\
\text { foremen }\end{array}$ & 0.023 & 0.150 & 0.036 & 0.186 & 0.000 & 0.000 \\
\hline White collar worker & 0.322 & 0.467 & 0.000 & 0.000 & 1.000 & 0.000 \\
\hline $\begin{array}{l}\text { Part-time employee } \\
(1=\text { yes })\end{array}$ & 0.034 & 0.182 & 0.000 & 0.000 & 0.000 & 0.000 \\
\hline Married employee (1 = yes) & 0.646 & 0.478 & 0.640 & 0.480 & 0.646 & 0.478 \\
\hline Foreign employee ( 1 = yes) & 0.131 & 0.337 & 0.183 & 0.387 & 0.033 & 0.178 \\
\hline $\begin{array}{l}\text { Logarithm of establishment } \\
\text { size }\end{array}$ & 7.509 & 1.297 & 7.517 & 1.308 & 7.513 & 1.269 \\
\hline $\begin{array}{l}\text { Logarithm of establishment } \\
\text { size squared (divided by } \\
100 \text { ) } \\
\text { Proportions within total } \\
\text { workforce of plant: }\end{array}$ & 0.581 & 0.194 & 0.582 & 0.195 & 0.581 & 0.190 \\
\hline Female workers & 0.131 & 0.097 & 0.184 & 0.152 & 0.209 & 0.134 \\
\hline Foreign workers & 0.100 & 0.088 & 0.140 & 0.101 & 0.114 & 0.089 \\
\hline $\begin{array}{l}\text { Workers with graduate } \\
\text { degree }\end{array}$ & 0.034 & 0.043 & 0.079 & 0.068 & 0.140 & 0.108 \\
\hline Part-time employees & 0.197 & 0.150 & 0.030 & 0.039 & 0.037 & 0.038 \\
\hline $\begin{array}{l}\text { Economic performance of } \\
\text { establishment (reference: } \\
\text { average performance) }\end{array}$ & & & & & & \\
\hline Good & 0.234 & 0.423 & 0.227 & 0.419 & 0.245 & 0.430 \\
\hline Bad & 0.391 & 0.488 & 0.394 & 0.489 & 0.389 & 0.487 \\
\hline
\end{tabular}




\begin{tabular}{|c|c|c|c|c|c|c|}
\hline $\begin{array}{l}\text { Paid overtime work in } \\
\text { establishment ( } 1=\text { yes) }\end{array}$ & 0.899 & 0.301 & 0.898 & 0.303 & 0.906 & 0.292 \\
\hline \multicolumn{7}{|l|}{$\begin{array}{l}\text { Collective agreement } \\
\text { (reference: no collective } \\
\text { agreement) }\end{array}$} \\
\hline at sectoral level & 0.929 & 0.257 & 0.925 & 0.263 & 0.936 & 0.245 \\
\hline at firm level & 0.051 & 0.220 & 0.056 & 0.229 & 0.043 & 0.202 \\
\hline $\begin{array}{l}\text { Use of technology (index, } \\
1=\text { new, } 5=\text { old) }\end{array}$ & 1.986 & 0.653 & 1.990 & 0.661 & 1.979 & 0.635 \\
\hline $\begin{array}{l}\text { Establishment formation in } \\
\text { the last } 5 \text { years }(1=\text { yes })\end{array}$ & 0.059 & 0.235 & 0.058 & 0.234 & 0.062 & 0.240 \\
\hline \multicolumn{7}{|l|}{$\begin{array}{l}\text { Year Dummies (reference: } \\
\text { year }=1995 \text { ) }\end{array}$} \\
\hline 1996 & 0.336 & 0.472 & 0.331 & 0.471 & 0.344 & 0.475 \\
\hline 1997 & 0.354 & 0.478 & 0.354 & 0.478 & 0.353 & 0.478 \\
\hline $\begin{array}{l}\text { Number of observations: } \\
\text { total (censored) }\end{array}$ & \multicolumn{2}{|c|}{$\begin{array}{l}1,860,710 \\
(224,853)\end{array}$} & \multicolumn{2}{|c|}{$\begin{array}{c}1,198,254 \\
(20,326)\end{array}$} & \multicolumn{2}{|c|}{$\begin{array}{c}598,968 \\
(203,898)\end{array}$} \\
\hline
\end{tabular}

Source: LIAB 1995-1997. 


\section{REFERENCES}

Abowd, John and Kramarz, Francis. 1999. "The Analysis of Labor Markets using Matched Employer-Employee Data" in: Orley Ashenfelter and David Card (eds.), Handbook of Labor Economics, vol. 3B, Amsterdam: Elsevier Science, 2629-2710.

Arnold, Jens Matthias and Katrin Hussinger. 2004. "Export Behavior and Firm Productivity in German Manufacturing. A Firm-level Analysis." Centre for European Economic Research Discussion Paper No. 04-12, Mannheim, January.

Aw, Bee Yan and Geeta Batra. 1999. "Wages, firm size, and wage inequality: How much do exports matter?" in: David B. Audretsch and A. Roy Thurik (eds.), Innovation, Industry Evolution, and Employment. Cambridge, UK: Cambridge University Press, 13-56.

Bender, Stefan, Anette Haas and Christoph Klose. 2000. "The IAB Employment Subsample 1975-1995", Schmollers Jahrbuch / Journal of Applied Social Science Studies 120 (4), 649-662.

Bernard, Andrew B. 1995. "Exporters and Trade Liberalization in Mexico: Production Structure and Performance." mimeo, MIT, Boston, February.

Bernard, Andrew B. and J. Bradford Jensen. 1995. "Exporters, Jobs, and Wages in U.S. Manufacturing: 1976-1987." Brookings Papers on Economic Activity, Microeconomics, 67-119. Washington, DC.

Bernard, Andrew B. and J. Bradford Jensen. 1999. "Exceptional Exporter Performance: Cause, Effect, or Both?" Journal of International Economics 47 (1), 1-25.

Bernard, Andrew B. and J. Bradford Jensen. 2001. "Why Some Firms Export." mimeo, Tuck School of Business, Dartmouth College, Hanover, April (Version 4.0; first version April 1997).

Bernard, Andrew B. and Joachim Wagner. 1997. "Exports and Success in German Manufacturing." Weltwirtschaftliches Archiv / Review of World Economics 133 (1), 134-157.

Farinas, José C. and Ana Martin-Marcos. 2003. "Exporting and Economic Performance: Firm-level Evidence for Spanish Manufacturing." mimeo, Universidad Complutense, Madrid.

Hahn, Chin Hee. 2004. "Exporting and Performance of Plants: Evidence from Korean Manufacturing." National Bureau of Economic Research, NBER Working Paper Series No. 10208, January.

Hansson, Pär and Nan Nan Lundin. 2003. "Exports as an Indicator on or Promoter of Successful Swedish Manufacturing Firms in the 1990s." Mimeo, Trade Union Institute for Economic Research (FIEF), Stockholm, and Örebro University, August. 
Isgut, Alberto E.. 2001. "What's Different about Exporters? Evidence from Colombian Manufacturing." Journal of Development Studies 37 (5), June, 5782.

Kölling, Arnd. 2000. "The IAB-Establishment Panel". Schmollers Jahrbuch / Journal of Applied Social Science Studies 120(3), 291-300.

Liu, Jin-Tan, Meng-Wen Tsou and James K. Hammitt. 1999. "Export Activity and Productivity: Evidence from the Taiwan Electronics Industry." Weltwirtschaftliches Archiv / Review of World Economics 135 (4), 675-691.

Meller, Patricio. 1995. "Chilean Export Growth, 1970-1990: An Assessment". In: G. K. Helleiner (Ed.), Manufacturing for Export in the Developing World. Problems and Possibilities. London and New York: Routledge, 21-53.

Sinani, Evis. 2003. "Export Market Participation: The Importance of Sunk Costs and Spillovers." Mimeo, Center for East European Studies, Copenhagen Business School, March.

Tsou, Meng-Wen, Jin-Tan Liu and James K. Hammitt. 2002. "Exporting and Productivity". Mimeo, Harvard School of Public Health, Boston, December.

Van Biesebroeck, Johannes. 2003. "Exporting raises Productivity in Sub-Saharan African Manufacturing Plants." National Bureau of Economic Research NBER Working Paper 10020, October.

Verhoogen, Eric. 2003. "Trade, Quality Upgrading and Wage Inequality in the Mexican Manufacturing Sector: Theory and Evidence from an ExchangeRate Shock." mimeo, University of California, Berkeley.

Wagner, Joachim. 2002. "The causal effects of exports on firm size and labor productivity: First evidence from a matching approach." Economics Letters $77,287-292$.

Zhou, Li. 2003. "Why do Exporting Firms Pay Higher Wages?" mimeo, Emory University, Atlanta. 